\title{
EVALUATION OF FOUR DIFFERENT SERUM ENZYMES IN THE DIAGNOSIS OF ACUTE MYOCARDIAL INFARCTION
}

\author{
BY \\ NIS I. NISSEN, P. RANLØV, AND J. WEIS-FOGH \\ From the Department of Medicine and the Central Laboratory, Sundby Hospital, Copenhagen, Denmark \\ Received July 13, 1964
}

The introduction of serum glutamine oxalacetic acid transaminase determination (GOT) in 1954 marked an important step forward in the diagnosis of acute myocardial infarction. At the same time, it formed the basis of recent advances in diagnostic enzymology (LaDue, Wróblewski, and Karmen, 1954). In the diagnosis of myocardial infarction alone, 8-10 different enzymes are used, but most of these tests do not yield more than the original GOT (Hess, 1962). Next to GOT, most interest has been focused on lactate dehydrogenase (LDH), $\alpha$-hydroxybutyrate dehydrogenase (HBD), and more recently on creatine phosphokinase (CPK).

As yet, organ-specific enzymes have not been demonstrated in the myocardium, so that only the increase in the activity of plasma non-specific cellular enzymes in the blood has been of diagnostic significance. With the advent of clinically applicable isoenzyme determinations this will possibly change, as the isoenzyme pattern characteristic of myocardial LDH appears to be present only in conditions involving myocardial necrosis (Møller and Raabo, 1964). The original LDH fractionation technique, starch gel electrophoresis, was not suitable for routine clinical use. Great interest was, therefore, displayed in the "chemical" determination of the myocardial LDH isoenzyme which appeared to be rendered possible by Rosalki and Wilkinson's finding that LDH reduced not only pyruvate to lactate, but also $\alpha$-ketobutyrate to $\alpha$-hydroxybutyrate, and that this property was particularly marked in the fast-moving fractions of the LDH molecule, i.e. the "myocardial isoenzymes" (Rosalki and Wilkinson, 1960). At the onset, it was not definitely known whether the butyrate action was due to an enzyme (HBD) different from LDH, but now it seems to have been finally proved that LDH possesses both properties (Hanson, 1962; Wieme, 1962). The presumption that the HBD activity in the serum represented particularly the activity of myocardial isoenzymes was supported by the finding of an HBD ratio for cardiac tissue/hepatic tissue of $4: 1$, while the corresponding ratio for LDH was 1:2 (Elliott and Wilkinson, 1961).

Most investigators have found that HBD was raised in all patients with confirmed myocardial infarction for up to 3 weeks after the acute episode (Elliott, Jepson, and Wilkinson, 1962; Elliott and Wilkinson, 1961, 1962; Hansson, Johansson, and Sievers, 1962; Konttinen and Halonen, 1962; Pagliaro and Notarbartolo, 1962). A finding of particular interest was that HBD proved to be normal in patients with diseases of the liver-biliary tract and diseases of the lung. In cases of doubt, the $\mathrm{HBD} / \mathrm{LDH}$ ratio gave further information, as a relative increase in HBD allegedly occurred only in patients suffering from cardiac or muscular diseases or from megaloblastic anæmia (Elliott et al., 1962). In daily investigations of 60 patients with myocardial infarction, Konttinen and Halonen (1962) found a positive HBD result on the third day in 92 per cent of the patients, but they have reservations about the differential diagnostic value of this enzyme because, for instance, they found an increased HBD activity in some cases of pneumonia. 
In the light of these observations, we felt that it would be of interest to adopt the HBD analysis as a routine method and to compare its value with a method, introduced almost at the same time, for analysing another relatively muscle-specific cellular enzyme, creatine phosphokinase (CPK).

CPK determination was introduced into clinical use in 1959 when Ebashi and his associates demonstrated raised CPK activity in the blood of patients with primary muscular diseases, later confirmed by others (e.g. Hughes, 1962). The use of CPK in the diagnosis of myocardial infarction was introduced by Dreyfus et al. (1960) who found a distinct increase in this enzyme in the serum of patients with recent myocardial infarction. This was confirmed by a number of others (Forster and Escher, 1961; Scebat, Renais, and Lenègre, 1961; Colombo, Richterich, and Rossi, 1962; Hughes, 1962; Schneider and Heise, 1963; Sørensen, 1963). While most of these authors favoured introducing CPK analysis as a routine method for clinical use, Schneider and Heise (1963) were more sceptical, especially as non-specific actions by striated muscles too often give rise to "false" results.

The object of the present study was to compare the applicability of two of the "more recent" enzyme determinations, CPK and HBD, with the more firmly established GOT and LDH analyses.

\section{SubJeCtS AND METHODS}

Serum enzyme analyses on venous blood were performed in 130 patients, 55 of whom had acute myocardial infarction where the occurrence of the episode could be fixed within an interval of 2 hours. The other 75 patients comprised 12 with angina pectoris, 16 with other heart diseases, and 47 patients suffering from non-cardiac diseases (Table I). In all the patients with myocardial infarction, GOT, CPK, LDH, and HBD analyses were made on venous blood drawn every 6 hours during the first 24 hours after admission and thereafter once daily, until all values were normal. The diagnosis of infarction was based on clinical criteria aided by an increase in the erythrocyte sedimentation rate, leucocytosis, electrocardiographic changes, increase in temperature, and a raised SGOT.

TABLE I

Distribution OF CASES

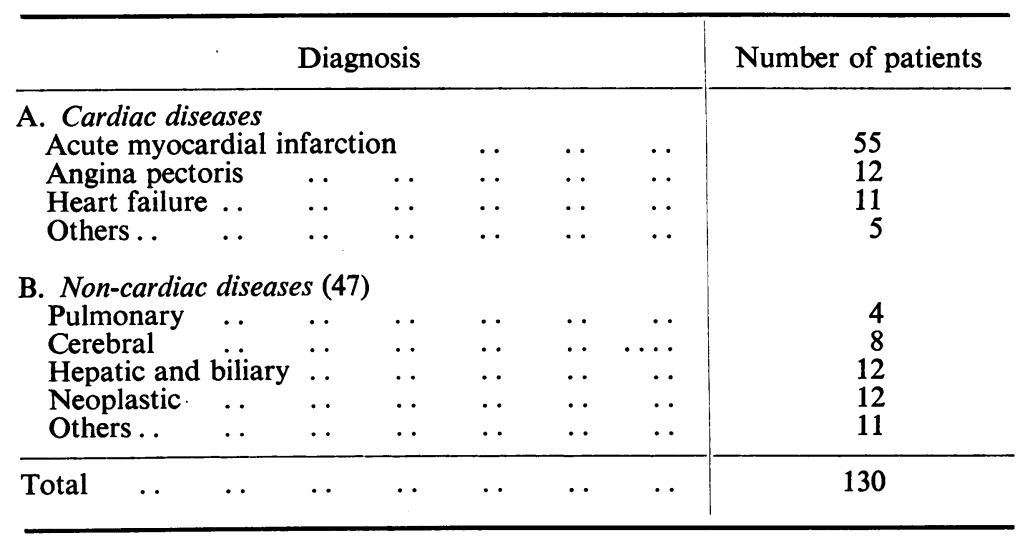

Determinations of serum GOT (Henley and Pollard, 1955), LDH (Wróblewski and LaDue, 1955), HBD (Elliott and Wilkinson, 1961, 1962), and CPK (Tanzer and Gilvarg, 1959) were carried out with reagents from Sigma and Boehringer. As a terminal phase, all four methods have a pyridine-nucleotide system in which the extinction fall in the reaction DPNH $+\mathrm{H}^{+} \rightarrow \mathrm{DPN}+$ is measured in a Beckman DU spectrophotometer $\left(340 \mathrm{~m} \mu\right.$ in a $10 \mathrm{~mm}$. cuvette at $25^{\circ} \mathrm{C}$.). The activities for all 4 enzymes are given as $\mu \mathrm{U} / \mathrm{min}$., corresponding to $\mu \mathrm{Mol} . / \mathrm{ml} . / \mathrm{min}$. converted DPNH.

The normal ranges for LDH, HBD, and CPK were determined on blood samples from 40 normal adults (medical and nursing staff, and medical students). No age or sex differences were found in the normal 
Normal Ranges and Analytical Constants used in Determining Glutamine Oxalacetic Acid Transaminase (GOT), Lactate Dehydrogenase (LDH), $\alpha$-Hydroxybutyrate Dehydrogenase (HBD), and Creatine PhosphoKINASE (CPK) IN SERUM

\begin{tabular}{l|c|c|c|c|c}
\hline Enzyme & $\begin{array}{c}\text { Normal range (95\%) } \\
\mu \mathrm{U} . / \mathrm{ml} . / \mathrm{min} .\end{array}$ & $\begin{array}{c}\text { Incubation } \\
\text { temperature } \\
\left({ }^{\circ} \mathrm{C} .\right)\end{array}$ & $\begin{array}{c}\text { Length of } \\
\text { incubation } \\
(\text { min.) }\end{array}$ & $\begin{array}{c}\text { Reading } \\
\text { (min.) }\end{array}$ & $p \mathrm{H}^{*}$ \\
\hline GOT & $0.35-1.55$ & $37^{\circ}$ & 10 & 2 & $7 \cdot 40$ \\
LDH & $3 \cdot 4-9 \cdot 8$ & $25^{\circ}$ & 30 & $7 \cdot 39$ \\
HBD & $2 \cdot 4-6.5$ & $25^{\circ}$ & 30 & 6 & $7 \cdot 39$ \\
CPK & $0.0-1.5$ & $25^{\circ}$ & 10 & $10 \dagger$ & $8 \cdot 68$ \\
\hline
\end{tabular}

* $p \mathrm{H}$ estimated by means of a glass micro-electrode and $\mathrm{pH}$-meter 22 (Radiometer) at the respective temperatures.

$\dagger$ Following addition of creatine buffer solution.

values. The normal range for SGOT is derived from a previous normal series. The analytical constants and normal ranges are listed in Table II.

All blood samples were obtained with a minimum of stasis and immediately centrifuged to prepare serum. If the serum could not be analysed immediately the specimens were deep frozen at $-25^{\circ} \mathrm{C}$. and analysed the following morning. This procedure did not reduce the enzyme activity. Serum specimens with hæmolysis were discarded.

\section{RESULTS}

In assessing the value of an enzyme estimation in the early diagnosis of acute myocardial infarction, the time when an increase occurs and the time of maximum serum activity are of decisive importance. From Fig. 1 it will be seen that CPK, which was raised in half the cases as early as the 3rd-6th hour with its maximum activity occurring in the 12th-24th hour after the onset of infarction, was in this respect the "best" enzyme, closely followed by SGOT. The LDH and HBD activities increased more slowly, reaching a peak on the 2 nd or $3 \mathrm{rd}$ day. On the other hand, the increase in

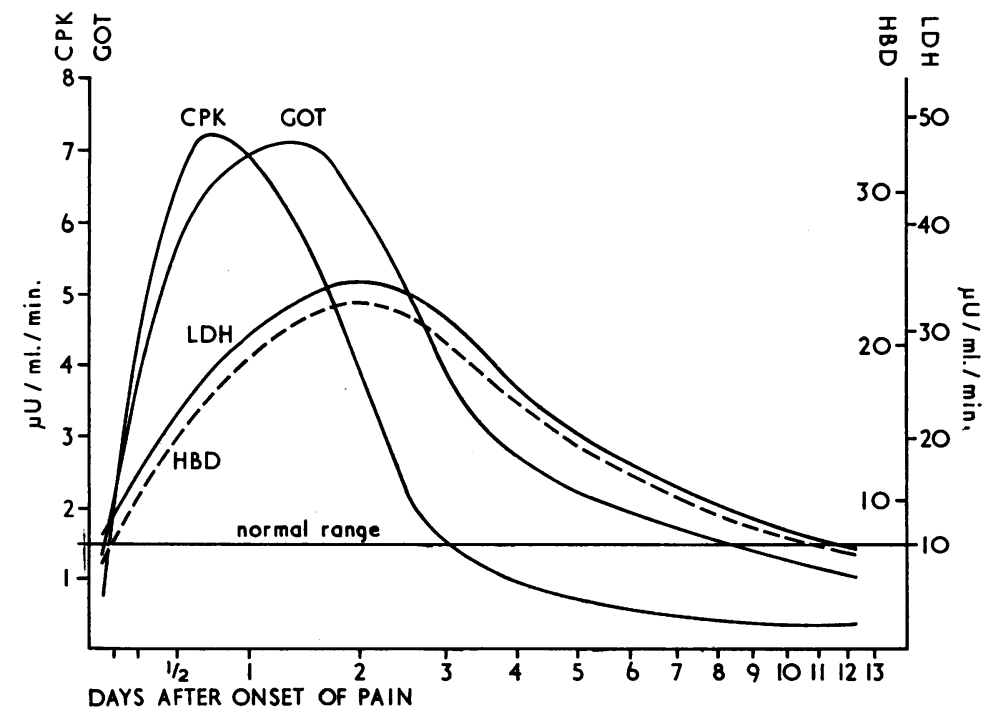

FIG. 1.-Mean time activity relation of 4 serum enzymes in 55 patients with acute myocardial infarction. (CPK $=$ creatine phosphokinase, GOT = glutamine oxalacetic acid transaminase, $\mathrm{HBD}=\alpha$ hydroxybutyrate dehydrogenase, $\mathrm{LDH}=$ lactate dehydrogenase.) 

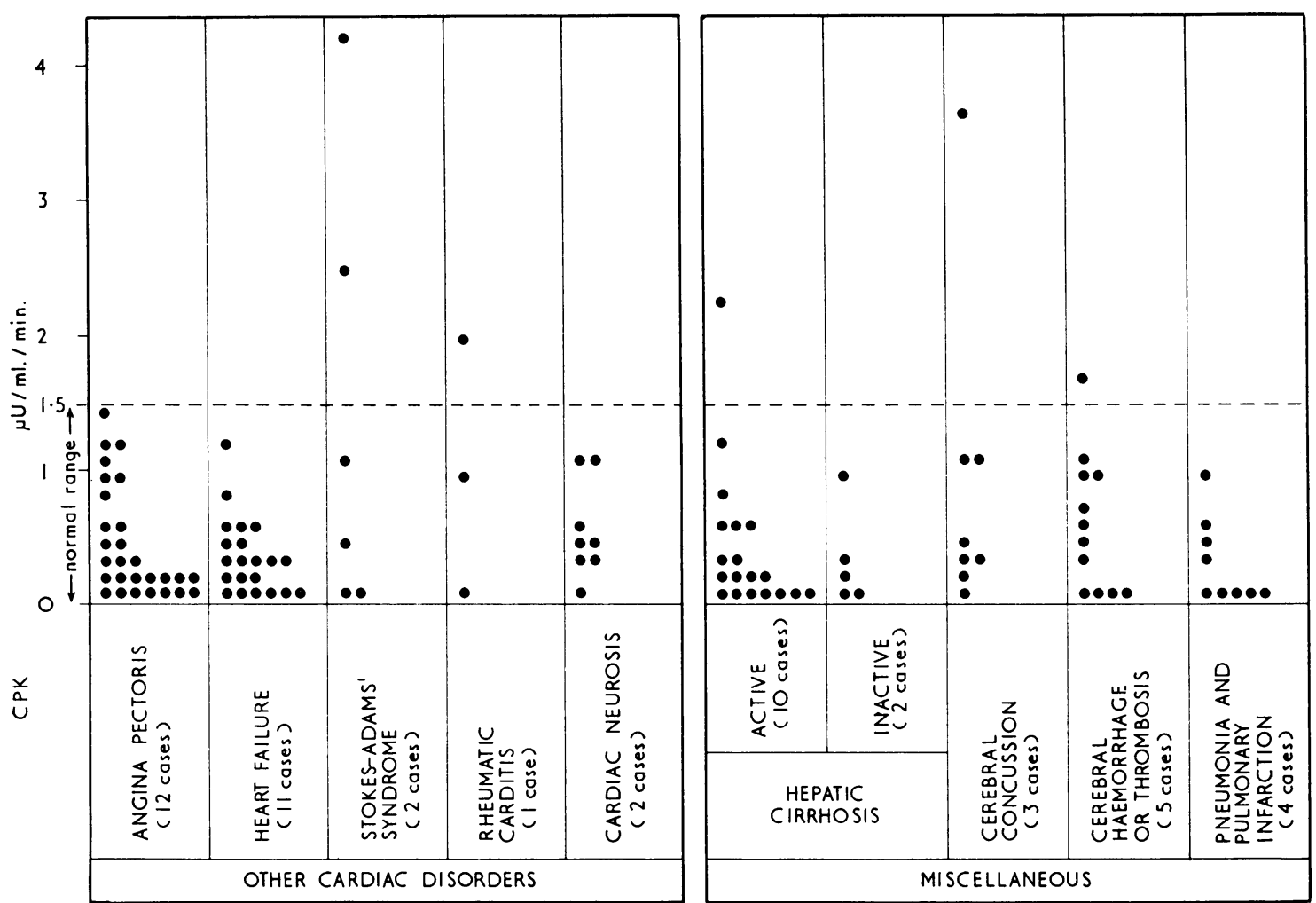

FIG. 2.-Creatine phosphokinase (CPK) activity in the serum of patients with non-occlusive cardiac diseases and other conditions.

these two enzymes lasted longer, as the activity in most cases did not return to normal until the 10th-12th day. In the late diagnosis, therefore, LDH and HBD are the most suitable enzymes.

The optimum result of CPK analysis apparently may be expected in the 12 th- 24 th hour $(89 \%$ positive), of the SGOT determination on the 2 nd day ( $98 \%$ positive), of the LDH determination on the 4 th day ( $100 \%$ positive), and of the HBD determination on the 2 nd day $(96 \%$ positive). As far as the last two enzymes are concerned, there were no differences on the 2 nd -4 th days.

The use of serial analyses appreciably reduced the number of false negative results. Thus, all CPK values were found to be normal in only one patient who was admitted on the 2 nd day. In this case, a possible increase may have subsided (the activity of the other 3 enzymes was distinctly increased). GOT, LDH, and HBD were normal in one patient who died within 24 hours (CPK 3.92). The HBD was normal in one patient who had shown a moderate increase in all the other enzymes for several days.

None of the enzymes showed significant differences between men and women or between patients having anterior wall and posterior wall infarcts. Patients who died had higher maximum values than the average.

Figure 2 gives the distribution of the CPK values in patients with diseases other than acute myocardial infarction. No patients with angina pectoris (a total of 12) or heart failure (a total of 11) had raised CPK values. On the other hand, a raised GOT was found in 3 and a raised LDH as well as HBD in 6 patients with heart failure. A suspicion of coronary occlusion was not entertained in any of these cases. Isolated increases in GOT, LDH, or HBD were observed in 3 patients with angina pectoris, $\mathrm{LDH}+\mathrm{HBD}$ increase in one, and GOT + LDH + HBD increase in one.

Raised CPK values were found in a few patients suffering from non-cardiac diseases, stroke, 
TABLE III

Enzyme Activity in Serum of 9 Patients Before and After Major Surgical Procedures

\begin{tabular}{c|c|c|c|c|c}
\hline \multirow{2}{*}{ Enzyme } & \multicolumn{5}{|c}{ Enzyme activity $(\mu \mathrm{U} . / \mathrm{ml} / \mathrm{min})}$. \\
\cline { 2 - 5 } & \multicolumn{2}{|c|}{ 1st day } & 2nd day & 3rd day & 4th day \\
\cline { 2 - 5 } & pre-op. & post-op. & & & \\
& 8.00 a.m. & 3.00 p.m. & 8.00 a.m. & 8.00 a.m. & 8.00 a.m. \\
\hline CPK & 0.24 & 1.45 & 3.58 & 3.25 & 1.94 \\
GOT & 1.12 & 2.60 & 2.46 & 1.68 & 1.95 \\
LDH & 6.66 & 10.06 & 9.66 & 7.65 & 7.00 \\
\hline
\end{tabular}

Operations finished at $10.00-12.00$ a.m.

TABLE IV

HBD/LDH Ratio in Serum of Patients with Acute Myocardial Infarction, other Cardiac and Non-Cardiac DISEASES

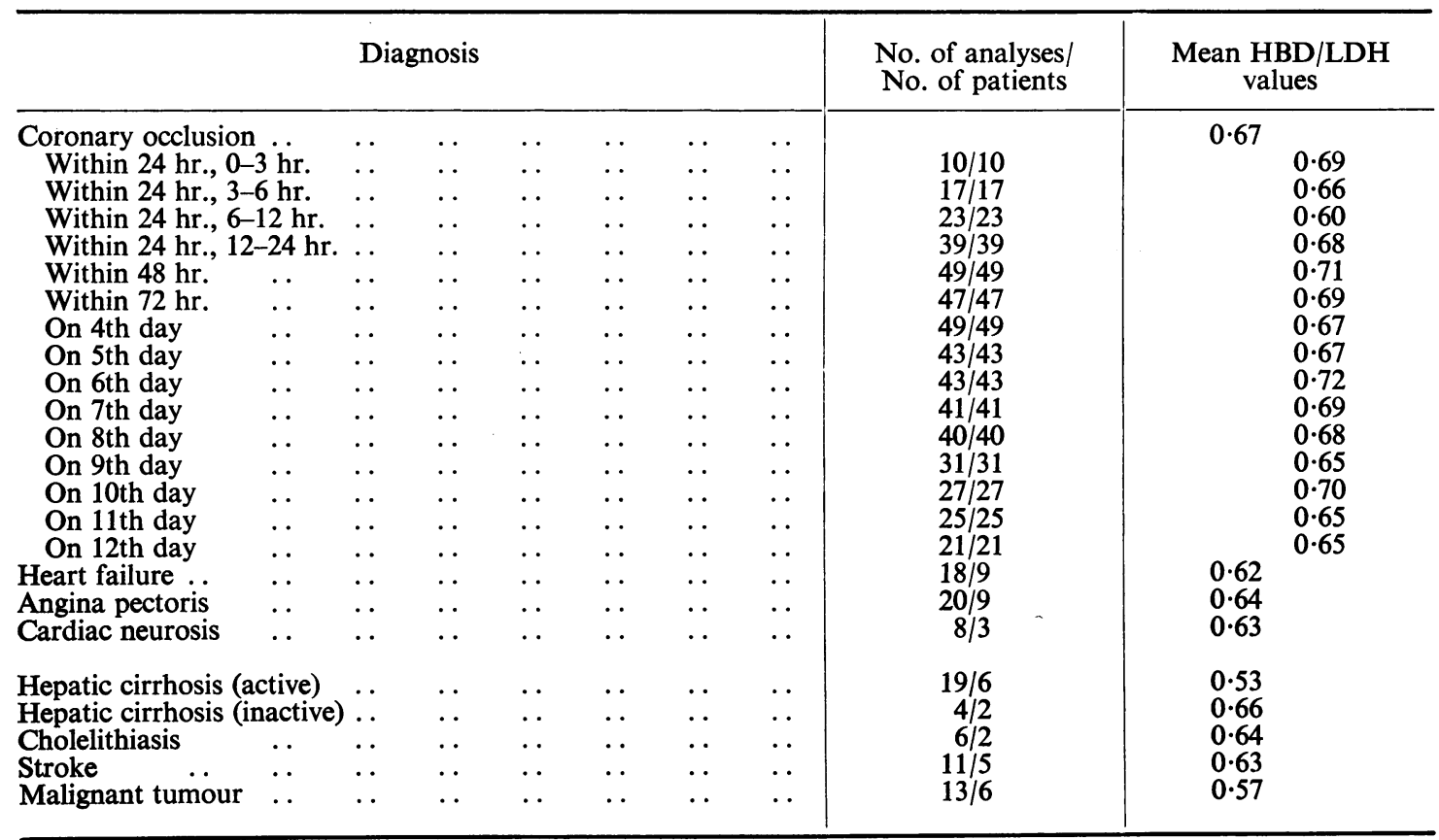

thyrotoxicosis, hepatic coma, and advanced metastatic cancer, while the CPK activity was normal in pleural effusions and ascites caused by cardiac decompensation or neoplastic disease.

From Table III it is seen that major surgery gave rise to an increase in the enzymatic activity in the serum, presumably due to the incision of striated muscles.

In Table IV the HBD/LDH ratio is calculated for the majority of the patients. The variations from group to group are not significant.

\section{Discussion}

The diagnostic use of a raised serum level of intracellular enzymes involves a number of pitfalls. Since, in diagnosing myocardial infarction, we are dealing exclusively with organ non-specific 
enzymes, an increase can be interpreted only as a sign of a local action upon the myocardium provided first that local actions upon other organs can be ruled out and second that general metabolic disturbances are not present. The difficulty of distinguishing between these factors may be illustrated by a few examples.

A patient with acute rheumatic carditis is being treated with high doses of salicylic acid. An increased activity of CPK and GOT in the serum may be due to myocarditis as well as to a general metabolic effect of the salicylic acid (Drivsholm and Madsen, 1961).

A patient is admitted with angina pectoris following strenuous physical exercise. An increase in CPK may be due to myocardial anoxia (infarction) as well as to hypoxia of striated muscles (physiological phenomenon following exercise) (Colombo et al., 1962).

A patient recently operated on has a heart attack. An increase in GOT and CPK may be due to myocardial infarction, incision of striated muscles, or to a general metabolic effect of the anæsthetic.

Theoretically, it is hardly possible to differentiate, on the basis of a single enzyme analysis, between local action on an organ and a general metabolic disturbance. On the other hand, there is a greater likelihood of being able to distinguish between the various local actions upon different organs. The introduction of the HBD analysis was expected to afford a more specific method for organ differential diagnosis, as it seemed likely that HBD represented the myocardium-specific fraction of $\mathrm{LDH}$. However, experience of HBD proved disappointing, and the enzyme appeared to behave exactly like total $\mathrm{LDH}$, evident also from the fact that the $\mathrm{HBD} / \mathrm{LDH}$ ratio was constant and of no diagnostic importance.

Theoretically, the almost muscle-specific enzyme CPK ought to afford advantages above GOT and LDH. Its activity is increased in $90-100$ per cent of patients with myocardial infarction, the enzyme is not present in the lungs or liver, and it is usually possible to rule out muscular diseases on the basis of the history. However, it is an advantage as well as a disadvantage of this enzyme that it is so easily released from the muscle cells. It is an advantage in that even small myocardial infarctions are demonstrable, but a disadvantage in that striated muscle readily gives off this enzyme to the blood-stream (Colombo et al., 1962; Schneider and Heise, 1963). Moreover, it is uncertain whether CPK can contribute to the differential diagnosis between angina pectoris and myocardial infarction. In the present series, it is true, CPK was found to be normal in all patients with angina pectoris, but other authors have found raised CPK in a large proportion of these patients. This may, however, be due to the use of different diagnostic criteria (Forster and Escher, 1961; Schneider and Heise, 1963).

Accordingly, the advantages of CPK over GOT are modest. Nevertheless, we believe that owing to its relative tissue-specific occurrence CPK deserves a place in the diagnosis of recent myocardial infarction, pending the advent of better methods.

\section{CONCLUSION}

As a result of this study we now use routinely the GOT + CPK determination when the presumed infarction is of less than 48 hours' duration, and the GOT + LDH determination when it is of several days' standing. We see no reason to continue using the HBD analysis.

Very probably, however, the CPK, GOT, as well as LDH determinations, will soon be abandoned and replaced by more organ-specific enzyme studies. This development has been initiated by the electrophoretic separation of $\mathrm{LDH}$, and routine methods for the fractionation of other enzymes are being developed. As a result enzymatic diagnosis will become more exact, but not less complicated.

\section{SUMMARY}

On the basis of serial analysis, the diagnostic value of the four enzymes, creatine phosphokinase (CPK), glutamine oxalacetic acid transaminase (GOT), lactate dehydrogenase (LDH), and $\alpha$ hydroxybutyrate dehydrogenase (HBD) was studied in the sera of 130 patients. A group of 55 had 
acute myocardial infarction, confirmed by the usual clinical criteria, including electrocardiographic changes and increase of GOT.

In all 55 cases the time of onset of the occlusion could be fixed within an interval of 2 hours. As a result, the onset of an increase and the time of maximum serum activity of each individual enzym'e could be accurately recorded. The optimum result of a CPK analysis was obtained 12-24 hours after the episode ( $89 \%$ positive), of the GOT analysis on the 2 nd day ( $98 \%$ positive), of the HBD analysis on the 2 nd day ( $96 \%$ positive), and of the $\mathrm{LDH}$ analysis on the 4 th day (100\% positive). In the present study the $\mathrm{HBD}$ was not superior to $\mathrm{LDH}$, the serial analyses showing a complete parallelism between the serum activities of these 2 enzymes. The CPK proved to be normal in 12 patients with angina pectoris and in 11 patients with heart failure. A number of these patients had raised GOT and $\mathrm{LDH}$ values.

It is concluded that the combination of CPK-GOT is best suited for the early diagnosis of acute myocardial infarction, while the combination GOT-LDH is most suitable in its later diagnosis.

The investigations were aided by grants from the F. L. Smidth Jubilee Foundation and from the Henry L. and Grace Doherty Charitable Foundation.

\section{REFERENCES}

Colombo, J. P., Richterich, R., and Rossi, E. (1962). Serum-Kreatin-Phosphokinase: Bestimmung und diagnostische Bedeutung. Klin. Wschr., 40, 37.

Dreyfus, J.-Cl., Schapira, G., Resnais, J., and Scebat, L. (1960). La créatine-kinase sérique dans le diagnostic de l'infarctus myocardique. Rev. franç. Étud. clin. biol., 5, 386.

Drivsholm, Aa., and Madsen, S. (1961). The influence of treatment with sodium salicylate on the serum glutamic oxalacetic transaminase activity. Scand. J. clin. Lab. Invest., 13, 442.

Ebashi, S., Toyokura, Y., Momoi, H., and Sugita, H. (1959). High creatine phosphokinase activity of sera of progressive muscular dystrophy. J. Biochem. (Tokyo), 46, 103.

Elliott, B. A., Jepson, E. M., and Wilkinson, J. H. (1962). Serum $\alpha$-hydroxybutyrate dehydrogenase-A new test with improved specificity for myocardial lesions. Clin. Sci., 23, 305.

- and Wilkinson, J. H. (1961). Serum " $\alpha$-hydroxybutyric dehydrogenase" in myocardial infarction and in liver disease. Lancet, $1,698$.

- and - (1962). The relative efficiencies of some serum-enzyme tests in the diagnosis of myocardial infarction. Lancet, $2,71$.

Forster, G., and Escher, J. (1961). Die Kreatinphosphokinase in der Diagnostik von Herzinfarkt und Myopathien. Helv. med. Acta, 28, 513.

Hanson, A. (1962). $\quad \alpha$-hydroxybutyrate dehydrogenase $v$. lactate dehydrogenase. Lancet, 2, 610.

Hansson, A., Johansson, B., and Sievers, J. (1962). Serum " $\alpha$-hydroxybutyric dehydrogenase" in myocardial infarction and in liver disease. Lancet, $1,167$.

Henley, K. S., and Pollard, H. M. (1955). A new method for determination of glutamic oxalacetic and glutamic pyruvic transaminase in serum. J. Lab. clin. Med., 46, 785.

Hess, B. (1962). Enzyme im Blutplasma. Thieme, Stuttgart.

Hughes, B. P. (1962). A method for the estimation of serum creatine kinase and its use in comparing creatine kinase and aldolase activity in normal and pathological sera. Clin. chim. Acta, 7, 597.

Konttinen, A., and Halonen, P. I. (1962). Serum $\alpha$-hydroxybutyric dehydrogenase (HBD) in myocardial infarction. Comparison with glutamic oxalacetic transaminase (GOT) and lactic dehydrogenase (LDH). Amer.J. Cardiol., 10, 525 .

LaDue, J. S., Wróblewski, F., and Karmen, A. (1954). Serum glutamic oxaloacetic transaminase activity in human acute transmural myocardial infarction. Science, 120, 497.

Møller, C. E., and Raabo, E. (1964). Diagnostic use of fractionated lactic dehydrogenase activity (LDH) in myocardial infarction. Acta med. scand., 175, 31.

Pagliaro, L., and Notarbartolo, A. (1962). $\alpha$-hydroxybutyric dehydrogenase in the diagnosis of myocardial infarction. Lancet, 1, 1043 .

Rosalki, S. B., and Wilkinson, J. H. (1960). Reduction of $\alpha$-ketobutyrate by human serum. Nature (Lond.), 188, 1110 .

Scebat, L., Renais, J., and Lenègre, J. (1961). La créatine-kinase sérique dans le diagnostic des lésions myocardiques. Arch. Mal. Cour, 54, 721 .

Schneider, K. W., and Heise, E. R. (1963). Die diagnostische Bedeutung einer erhöhten Kreatin-PhosphokinaseAktivität im Serum. Dtsch. med. Wschr., 88, 520.

Sørensen, N. S. (1963). Creatine phosphokinase in the diagnosis of myocardial infarction. Acta med. scand., 174, 725 .

Tanzer, M. L., and Gilvarg, C. (1959). Creatine and creatine kinase measurement. J. biol. Chem., 234, 3201.

Wieme, R. J. (1962). $\quad \alpha$-hydroxybutyric dehydrogenase in the diagnosis of myocardial infarction. Lancet, $2,304$.

Wróblewski, F., and LaDue, J. S. (1955). Lactic dehydrogenase activity in blood. Proc. Soc. exp. Biol. (N.Y.), 90, 210. 